\title{
Crystal stratigraphy of Taranaki lavas, New Zealand
}

\author{
Nessa D’MELlo ${ }^{1}$, Teresa UbidE ${ }^{2}$, GeORG F. \\ ZELLMER $^{1}$, JONATHAN PROCTER ${ }^{1}$, GABOR KERESZTURI ${ }^{1}$, \\ JOHN CAULFIELD ${ }^{3}$ \\ ${ }^{1}$ VRS, Massey University, Palmerston North, New Zealand \\ N.D’Mello@massey.ac.nz \\ ${ }^{2}$ University of Queensland, Brisbane, Australia \\ ${ }^{3}$ Queensland University of Technology, Brisbane, Australia
}

Recent lava flows of Taranaki volcano, located in the back arc region of the Hikurangi subduction zone, carry a crystal cargo previously identified as antecrysts [1]. LA-ICPMS element mapping of minor and trace elements reveals complex growth histories recorded in the major mineral phases of clinopyroxene, plagioclase and amphibole.

Clinopyroxene crystals include (i) resorbed cores mantled by sector zoned pyroxene; (ii) concentric zones of Ni (rarely Cr) enrichment; and (iii) HFSE enriched rims overgrowing unzoned and oscillatory zoned crystals. Plagioclase crystals are also zoned, often restricted to 3-4 step-zones, and include (i) normal zoning with Ba poor- and Li rich- cores; (ii) large oscillatory zoned crystals displaying sieve texture and $\mathrm{Sr}$ zoning; and (iii) small unzoned crystals with compositions similar to rims of larger plagioclase crystals. Amphibole chemistry is varied, displaying (i) oscillatory zoning with HFSE-enriched or -depleted cores and rims, (ii) distinct zones enriched with $\mathrm{Ni}$ and $\mathrm{Cr}$, (iii) oscillatory-zoned amphibole mantles over compositionally distinct cores which are high in REE and HFSE elements, and (iv) presence of resorbed foreign cores- wih different $\mathrm{Ca}$ concentrations. Sector- and normal- zoning is also observed along with unzoned crystals.

Most amphiboles show opacitization/ oxidation rims [2, $3,4]$. These reaction rims are high in HFSE and low in major elements such as $\mathrm{Al}, \mathrm{Na}$ and $\mathrm{Ca}$ relative to the cores.

The variations in zonation types within the same samples make it impossible to use zonation characteristics as a basis for lava flow discrimination. Furthermore, mineral abundances vary between different eruptive units of the same eruptive phase. The data indicate that eruptions from Taranaki are triggered by ascent of crystal-free melts remobilizing cargo from a sub-volcanic mush zone, investigated here through the crystal cargo. In contrast, assessment of melt generation conditions in the mantle will require groundmass chemical constraints.

[1] Stewart et al. (1996) J. Volcanol. Geotherm. Res 74(3-4), 275-295. [2] Plechov et al. (2008) Petrology 16(1), 19-35 [3] Rutherford and Hill (1993) J. Geophys. Res 98(B11), 619685 [4] Murphy et al. (2000) J. Petrol. 41(1), 21-42 